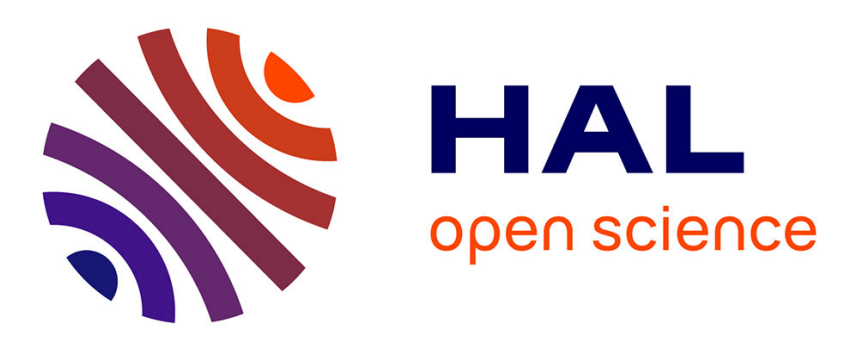

\title{
Between Competition Imperative and Europeanisation. The Case of Higher Education Reform in Poland
}

Dorota Dakowska

\section{To cite this version:}

Dorota Dakowska. Between Competition Imperative and Europeanisation. The Case of Higher Education Reform in Poland. Higher Education, 2015, 69 (1), pp.129-141. 10.1007/s10734-014-9765-6i . halshs-01183911

\author{
HAL Id: halshs-01183911 \\ https://shs.hal.science/halshs-01183911
}

Submitted on 14 Aug 2015

HAL is a multi-disciplinary open access archive for the deposit and dissemination of scientific research documents, whether they are published or not. The documents may come from teaching and research institutions in France or abroad, or from public or private research centers.
L'archive ouverte pluridisciplinaire HAL, est destinée au dépôt et à la diffusion de documents scientifiques de niveau recherche, publiés ou non, émanant des établissements d'enseignement et de recherche français ou étrangers, des laboratoires publics ou privés. 
Dorota Dakowska, « Between Competition Imperative and Europeanisation. The Case of Higher Education Reform in Poland », Higher Education, vol. 69, $\mathrm{n}^{\circ} 1,2015$, p. 129-141, DOI 10.1007/s10734-014-9765-6.

\section{Between Competition Imperative and Europeanisation. The Case of Higher}

\section{Education Reform in Poland}

While the Europeanisation of Higher Education (HE) systems has triggered much debate, the relationship between European factors and domestic economic processes, has been less thoroughly analysed. This article analyses HE reforms in the light of two parallel processes, which have shaped this sector: the introduction of market mechanisms and a gradual Europeanisation. The Polish HE makes a good case study of the relationship between both processes as it has been shaped by the contingencies inherent to the establishment of a liberal economic regime. Another set of inputs originated from the conditionality of the EU accession process, which coincided with the launching of the Bologna Process. While the postcommunist transformations entailed the large-scale privatisation of the HE system, the Bologna Process defined the role of the sector as supporting a 'knowledge-based economy', an agenda promoted by the Lisbon strategy and international institutions in the field. Trying to combine the study of policy practice and narratives this article takes into account the legislative outcomes as well as the reform debates based both on economic arguments and on the necessity to 'catch up with Europe'.

Keywords: Privatisation; Europeanisation; HE Reform; Poland; Bologna Process; competitiveness 
A large number of studies dealing with Higher Education (HE) transformations focus on the 'Europeanisation' of HE institutions (HEI) and systems (Amaral \& al. 2009; Bache 2006; Dale and Robertson 2009). The case of Central and Eastern European countries (CEECs) has attracted academic attention only relatively recently. While some authors have found that European pressures have resulted in a growing convergence between their HE systems (Dobbins and Knill 2009; Dobbins 2011), others note 'no significant Europeanisation' of the system they analyse (Pabian 2009). These apparently opposed conclusions are owed to differences in the research design, in the importance given to the European variable and, last but not least, in the very definition of Europeanisation. For many authors, Europeanisation has to do with the transfer of specific governance models from the EU to the domestic level (Radaelli, 2001). However, it is hard to apply this definition to the HE sector, as no formal model of HE organisation has been put forward by the European authorities. Moreover, notwithstanding the increasing role of the European Commission in the steering of HE reforms, the sector remains formally an intergovernmental competence. In case of the Bologna Process, behind the claimed convergence of general commitments to degree harmonisation, quality assurance and qualification frameworks, considerable divergences persist between European HE systems (Musselin 2009). However studies of policies promoted through the Open Method of Coordination (OMC) show that the absence of convergence does not imply an absence of Europeanisation' and call for a more precise analysis of mechanisms and agents of change (Graziano et al. 2011: 7). Finally, while several authors have acknowledged the link between the OMC applied to the European Higher Education and Research policies and the promotion of EU's competitiveness (Bruno 2008; Keeling 2006), much less attention has been paid to the way European frameworks may resonate with domestic neo-liberal economic policies. 
This article seeks to analyse the relationship between the domestic and European factors of HE reforms. Poland provides a useful case study as it has been shaped by two parallel processes since 1989: a far-reaching privatisation of its $\mathrm{HE}$ sector and a gradual Europeanisation. ${ }^{1}$ To grasp the relationship between the privatisation process and the adaptation to the EHEA, this contribution will focus on the domestic uses of the competitiveness narrative by actors involved in the reform design. The Polish case will be further replaced in a broader international context by referring to the experience of other countries situated both in CEE and in Western Europe. In order to explain the national framework of HE reform the following hypotheses can be advanced:

- The development of private HE is the result of a series of deliberate political decisions promoting the expansion of this sector. These decisions reflect an ideological climate favourable to neo-liberal ideas.

- This policy is challenged by EU and intergovernmental policies such as the Bologna Process, which promotes a convergence of domestic HE systems through the comparability of degrees, credit transfer, quality assurance and academic mobility.

The article is structured as follows. In "From market mechanisms to Europeanisation: the missing link?" I discuss the relationship between the transformations triggered or supported by EU policies and the opening up of the HE to market mechanisms, resulting in the partial privatisation of the sector. In "The legacy of the transition context: a far-reaching privatisation of HE", the expansion of Polish private HE education is explained in the light of the legislation adopted in the first decade after 1989. In "The injunction of competitiveness shaped by European policies" I analyse the circulation of reform narratives based on economic arguments and market rationales by experts involved in the debate on HE and the

\footnotetext{
1 This analysis is based on different types of documents related to the reforms (legal acts, published and unpublished reports as well as press articles) and on 25 semi-structured interviews with domestic, European and international education experts, top civil servants, MEPs and representatives of the Polish academic community, conducted in 2010-2013.
} 
reform design. I take into account the European and international factors such as the Bologna Process to see how they fuelled the reformist discourse.

\section{From market mechanisms to Europeanisation: the missing link?}

The assessment of the domestic answers to the ideas promoted and diffused within the European Higher Education Area hinges on the researchers' appraisal of the role played by the European Commission. Those who focus on the origins of the Bologna Process emphasize the formally limited prerogatives of the EU in the educational sector (Muller, Ravinet, 2009). Others point out that since the launch of the Bologna Process, the European Commission has adopted a much more proactive role (Keeling 2006). Authors who investigate the Commission's 'power of the purse' (Batory, Lindstrom, 2011) or, more broadly, its financial, informational and political resources argue that 'EU institutions do not require a formal shift of policy competence to exercise influence' (Bache 2006: 236).

As far as the relationship between the European and the domestic level in the HE sector is concerned, recent publications offer an interesting overview of its various aspects in terms of the impact of the Bologna Process (Curaj \& al., 2012) and of the more general effects of reforms on the academic profession (Vukasovic \& al., 2012). However, these studies often suffer from a Bologna bias, as they focus almost exclusively on the immediate effects of the construction of the EHEA and therefore overlook deeper policy trends and path-dependent HE trajectories at the domestic level.

A sociological and relational definition of Europeanisation is useful to refine the study of the relationship between ongoing processes at the European and domestic levels. According to this approach, the impact of European integration may be analysed not so much by measuring the degree and scope of policy or institutional adaptation, but through the various uses of the reference to Europe by domestic actors (Baisnée \& Pasquier 2007; Woll \& Jacquot 2010; 
Guiraudon \& Favell, 2011). This attention directed at the social and political uses of external recommendations allows for showing policy trajectories across different stages of reform. In CEEC, these reforms were subsequently informed by claims for HE intellectual and financial autonomy, emphasis on adaptation to European standards and ultimately the overwhelming ambition to play the global game of knowledge production. This is not to say that the analysed set of reforms can be considered as linear or that a coherent governmental strategy could be identified over the period. However, it is possible to show that European recommendations provide arguments to those of the domestic actors who wish to engage reforms and introduce more competition between HEI. These political logics may be compared to what Musselin (2009) has called a "re-nationalisation" effect when analysing the governmental uses of European recommendations in the French case.

As far as the relationship between neo-liberal transformations leading to the privatisation of the tertiary education and Europeanisation is concerned, both trends are usually considered separately. When the relationship between them is debated, conclusions may diverge. According to Kwiek (2007), the Bologna Process does not take into account the specificities of the private sector, which may be a risk for the HE in CEEC, as this sector has reached significant proportions in the region. For other authors, the establishment of a European Higher Education Area (EHEA) entails the subordination of universities and of knowledge production to market forces (Schultheis and al 2008; Walkenhorst 2008). I argue that both the initial reforms in CEEC, aimed at the liberalisation of the HE sector - and which resulted in its partial privatisation - and the more recent reforms justified by the adaptation to the EHEA and to global trends can be analysed jointly. Although the first reform cycle is perceived as part of the post-communist structural transformation and the second as a case of Europeanisation, they both have similar aims: the modernisation of the domestic Higher Education and Research system and the strengthening of its competitiveness in the light of a 
growing internationalisation. They also call for reflection on the role of the state in the light of processes seemingly liable to undermine its power from the inside (the expansion of private versus public tertiary education) and from the outside (European frameworks and standards as opposed to national policies and HEI autonomy).

The reforms of Higher Education (HE) in Poland have been a paradoxical process in several regards. While the expansion of the private HE sector, concomitant with the post-communist transition, has been spectacular, the state regardless still plays an important role in $\mathrm{HE}$ management. Moreover, the opening up of the HE sector to market mechanisms, undertaken after 1989, was not limited to the creation of private HE institutions (HEI), which started competing with more traditional public establishments. On the contrary, public universities themselves have been strongly affected by the lure of money. They have contributed to the expansion of the private sector by opening for-profit courses, diplomas and subsidiaries. Thus the analysis of the Polish case arguably contributes to the reflection on the necessary reconsideration of the public/private distinction in HE (Marginson 2007; Lane and Kinser 2011).

Concerning the very notion of privatisation, Neave (2007) points out that it is a tricky term, used to refer to realities that differ according to the country and the chosen disciplinary approach. While privatisation is often associated with marketisation (Marginson 2007) I propose to consider it along with other, broader trends to see how the European strategies aiming at the modernisation of Higher Education affect the economisation of the public discourse on HE. While it is acknowledged that European integration does not influence the member countries uniformly, it has to be demonstrated whether and how it articulates with neo-liberal discourses promoted at the domestic level.

\section{The legacy of the transition context: a far-reaching privatisation of $\mathrm{HE}$}


From a global point of view, the expansion of the private sector in Central and Eastern Europe is just one aspect of a much broader phenomenon, which has been branded a 'Global Revolution' (Altbach and Levy 2005). Although global in its reach, the growth of the educative private sector has not affected all the regions of the world in the same way (Krücken and Serrano-Velarde 2012; Levy 2012). While East Asian countries now have a very high proportion of private HEI, Western European countries tend to retain a strong public sector (Altbach 2005; Neave 2007). This raised a challenge for those CEEC that engaged in neo-liberal reforms while looking for inspiration in Western Europe. Thus, to understand the general pattern of the changes which affected HE systems it is important to consider the regional context, which in the case of formerly communist CEEC was characterised by efforts to reform, in order to put an end to the authoritarian past, and by the preparation for the EU accession.

A macro-political approach focusing on the general design of the reforms undertaken in the CEEC which have joined the EU during the last decade does not take into account their differential paths and degrees of privatisation. From a purely quantitative point of view, the expansion of private $\mathrm{HE}$ is a natural response to the growing educational demand in a liberalised market. Yet this commonplace statement does not cover the whole story. If this was the case, we would notice a similar expansion of private HE in all formerly communist countries. However, existing studies show that student enrolment in private HEI in CEEC varies from 3 or $4 \%$ (Croatia, Slovakia) to more than 30\% in countries like Estonia, Poland or Romania (Slantcheva and Levy 2007; Levy 2012). While in some countries legislative frameworks were reshaped to better accommodate the nascent private sector, in many others private HEI were merely tolerated and state regulation came later (ibid.). Thus, an explanation in terms of supply and demand is not sufficient to understand the rationale and mechanisms of 
the educational private sector's transformation. The persisting divergences between national systems require further explanation and deeper case studies.

After the fall of the communist regime, the Polish HE system underwent transformations that were in many respects similar to those of other countries from the region. These changes consisted in giving back a large degree of autonomy to the universities while opening them up to the market economy (Dobbins and Knill 2009). As a result, the Central European HE field joined in trends that had already been under way for decades in Western Europe, such as the massification of HE, the growing number of private schools and the increasing popularity of the view of teaching and research as a commodity and not (only) as a public good (Jabłecka 1994). Poland counts among the group of countries considered as forerunners in the expansion of the private sector, which gained significant proportions after 1989. This does not mean that the state has disengaged from the HE system as a whole. The established state intervention in matters such as accreditation or setting minimal standards of teaching has coexisted with the increasing market-based orientation of the sector.

The legal basis to the transformations of the Polish tertiary education was provided by the Higher Education Act of 12 September 1990. While the first and foremost aim of this legal framework was to grant a large autonomy to HEI, its second outcome was to open the door to a far-reaching marketisation of the sector. On the one hand, the Act meant to re-establish the conditions of academic freedom and self-government as a reaction to the centralised and politically controlled system of the communist state (World Bank 2004). Thus a great amount of decision-making power was devolved to collective and elected bodies as opposed to individual deans or rectors. On the other hand, this seminal HE Act was clearly geared to facilitate the development of non-public HEI. The latter are already mentioned in the first article of the document (HE Act 1990). Several provisions facilitate the creation and running of private HEI. Moreover, without limiting itself to the distinction between public and non- 
public establishments, the Act paves the way for the development of fee-charging courses by introducing the distinction between full time day studies, evening studies and extramural studies (art. 4). This reform has led to the progressive introduction of the BA degree, especially for fee-paying students, as many private HEI offered only short study programmes. Another Act on Higher Vocational Schools adopted in 1997 has further contributed to the development of the non-public sector. Notwithstanding this spectacular expansion of the nonstate sector, both the legal framework and the representative HE bodies recognised by the ministry of Education were largely dominated by the public HEI, at least until 2005 (Jabłecka 2007). Representatives of the private sector were barely present in the groups in charge of accreditation and defining teaching standards (ibid.)

The liberalisation and marketisation of the HE system in Poland resulted in the development of a very large private HE sector. Out of 453 HEI in Poland 132 are public and 321 nonpublic (GUS 2013). ${ }^{2}$ Strikingly, the proportion of students in private HEI is estimated higher in Poland than in the USA (Ernst\&Young 2010). Furthermore, the public and private sector are highly heterogeneous. Both universities and technical universities are for the most part public establishments, while a vast majority of economic academies, pedagogical institutions and higher vocational schools are private (Jabłecka 2007). At the same time, student numbers and participation rates have increased tremendously.

Contrary to what is sometimes said about the egalitarian orientation of the communist system, higher education tended to be reserved to an elite in this period as only $10 \%$ of the population had a HE degree. During the 1990s, several post-communist countries offered broader access to HE. As a result, the participation rates in tertiary education have quadrupled in Poland during the last two decades. The gross participation rate in HEI increased from $12,9 \%$ in

\footnotetext{
${ }^{2}$ While there was one non-public university at the end of the communist period, the number of non-public HEI reached 18 in 1992-93, 80 in 1995-96, 195 in 2000-2001, 326 in 2008-2009 and 338 in 2010-2011. Ministry of Science and Higher Education, Statistical data on HE. The Catholic University of Lublin was the only non-state university existing in 1989, which was an exception in the Soviet Bloc. In 2013, 27.4\% of all students studied in a private HEI (GUS, 2013).
} 
$1990-91$ to $51,8 \%$ in the academic year $2012-2013$ while the net participation rate increased from $9,8 \%$ to $40,2 \%$ (GUS 2013: 30 ). One third of all the students are enrolled in non-public HEI. Another part of this population studies at public HEI, but for a fee. Thus, although constitutionally $\mathrm{HE}$ is free of charge, $58 \%$ of the students de facto pay tuition fees (Ernst\&Young 2010). Although public HEI depend heavily on state budget, private students are an important source of revenue for them (see Table 1$){ }^{3}$

Table 1. Structure of revenues from teaching activity of HEI in Poland in 2012 (in \%)

\begin{tabular}{|l|l|l|l|l|l|}
\hline & Total & $\begin{array}{l}\text { Including: } \\
\text { Subsidies from }\end{array}$ & Funds from local & Fees for teaching & Other \\
& & State budget & $\begin{array}{l}\text { authorities } \\
\text { and other } \\
\text { public funds }\end{array}$ & activities & \\
\hline Public HEI & $100 \%$ & & $0.2 \%$ & $15.5 \%$ & $11.9 \%$ \\
\hline Non Public & $100 \%$ & $72.4 \%$ & $0.2 \%$ & $85.0 \%$ & $7.5 \%$ \\
\hline
\end{tabular}

Source: GUS (2013).

Concerning the structure of operating activity revenues of HEI as a whole, the most part comes nowadays from teaching activity, followed by research activity in the public sector, and other sources of income, including separate economic activities (Table 2). Clearly, private HEI are more teaching oriented and less research-intensive, although in both sectors, statutory public funding for research only constitutes a small part of their research revenues.

\section{Table 2. Structure of operating activity revenues of HEI in Poland in 2012 (in \%)}

\footnotetext{
3 During the last two decades the number of students grew from 403000 in 1990-1991 to 1930000 in the year 2007-2008, 1900000 in 2009-2010 and 1841251 in 2010-2011. For a general structure of operating activity revenues, see Table 1.

${ }^{4}$ As far as the revenues from research activities are concerned, they are highly diversified both in the public and in the private sector. In 2012, the share of state statutory subsidies was only $35.5 \%$ in the public sector and $20,3 \%$ in the private sector. The subsidies attributed on a competitive base for research projects were another
} 


\begin{tabular}{|l|l|l|l|l|}
\hline & Total & $\begin{array}{l}\text { Including: } \\
\text { Revenues from } \\
\text { teaching }\end{array}$ & Revenues from & Other \\
& & research & \\
\hline Public HEI & $100 \%$ & $76.9 \%$ & $15.9 \%$ & $7.2 \%$ \\
\hline Non Public & $100 \%$ & $84.8 \%$ & $3.6 \%$ & $11.6 \%$ \\
\hline
\end{tabular}

Source: GUS (2013).

\section{The injunction of competitiveness shaped by European policies}

The debates on HE governance and preferred models have involved experts, stakeholders and the political and administrative decision-makers. These debates addressed the question of the relationship between the public and private HE sector and the state, the quality of teaching and research, the academic career paths as well as the challenges of internationalisation. The HE reforms undertaken over the last decade were framed by transnational trends such as the Bologna Process or the growth of international university rankings. The 2005 HE Act was the first attempt to translate proposals elaborated during the Bologna ministerial meetings into a legal framework. This reform has been revised and updated by a new Act of March 2011 (Higher Education Act 2011), which entered into force in October 2011. ${ }^{5}$ These reforms are based on the observation of an insufficient competitiveness and visibility of Polish HEI. They refer, directly and indirectly, to the Bologna Process and the EHEA in order to increase the quality and efficiency of domestic HEI but also to strengthen their global position.

\footnotetext{
important source of revenue: $18.1 \%$ came from the National Science Centre in the public sector $(7.2 \%$ in the private sector) and $10.7 \%$ from the National Centre of Research and Development ( $28.6 \%$ in the private sector). International academic scientific cooperation brought $15.9 \%$ of research revenue to the public HEI and $6 \%$ to the private sector. The selling of R\&D services brought $12.1 \%$ to public HEI and $4,7 \%$ to the private HEI. Other revenues amounted to $14.1 \%$ of public HEI research revenues and $33.2 \%$ to private ones (GUS 2013, p. 51).

${ }^{5}$ A separate legal package reforming Polish Science has been, published on June $4^{\text {th }} 2010$ and entered into force on October $1^{\text {st }} 2010$. They aim at creating conditions for more private sector involvement in the financing of research. Interview with a high-ranking representative of the Ministry of Science and HE, Warsaw, 22 October 2011. The 2011 HE Act was updated in November 2012, including a raise of the retirement age for academic teachers.
} 
The private HE sector in the reform debates

The debate on the desirable form and reform of Polish HE has been shaped by the issue of the relationship between the private and the public sector and divergent appreciations of each of them. The spectacular rise of students' enrolment in HEI has been qualified as an 'educational miracle' (Ratajczak, 2004). Representatives of the non-public sector have claimed that their institutions gave the population living in small towns and rural areas access to tertiary education (Szabłowski 2004). However, the non-public sector has suffered from a weak professional legitimacy, due among others to its negative image as second-choice provincial establishments offering low quality education (Jabłecka 2007; Levy 2007). The fact that the non-public sector was for a long time de facto excluded from the applications for state subsidies has added to the tense relationship between both sectors (Jabłecka 2007). Finally the 2005 HE Act allowed for a gradual recognition of the non-public sector. However, some proreformist experts still criticise the persisting inequalities between both sectors (Interview $n^{\circ} 2$, 24 October 2010, HE expert, involved in a private HEI).

At the same time, reformist voices have criticised the public sector for its lack of internal incentives for the teaching staff to work more productively and loyally. They have called for more flexible working contracts and for more autonomy given to HEI in defining both the workload and the pay of their staff (Jackowski 2004). They disapproved the system of tenure contracts and called for a more competitive management system (Thieme 2009). In these debates the American (US) model was most frequently cited as a reference. As Guy Neave (2007: 29) recalls, the United States are 'the normative and referential system of higher education that sets the benchmarking for the policy of privatisation in this sector and others'. However, with the perspective of the EU accession and the creation of the EHEA, there have been increasingly more pleas for a far-reaching alignment of the domestic HE with the 
Bologna Process. It is therefore worth asking how these pledges for further privatisation and a stronger market orientation of HE combine with the desired Europeanisation of the sector.

\section{Adapting national legislation: between marketisation and Europeanization}

The debates on a necessary reform of the Polish HE were an opportunity for key actors to diffuse narratives on the threat of a growing backwardness of the country's academic system in the international context. This kind of discourse emphasises competition as an imperative. The 2005 HE Act was meant to provide a legal status to the main objectives of the Bologna Process concerning degrees harmonisation and credit transfer. The justification of this reform was the necessity to compete in the HE market of an enlarged EU, which Poland joined on May $1^{\text {st }} 2004$, to increase the quality of domestic HEI in order to avoid the risk of becoming marginalised in the common educational market. However, the 2005 Act was deemed insufficient by the reformist representatives of the academic community supported by the liberal government formed in 2007. These voices criticised the dire state of Polish HE and Research, as reflected in global university rankings. They called for a radical reform of HE governance and a stronger differentiation between HEI due to a 'fierce competition', which would allow the emergence of a few leaders (Jajszczyk 2008a).

The preparations of the recent legislative projects on HE illustrate the importance given to market-based considerations and the domestic uses of external policy references. In 2009, the Ministry of Science and Higher Education (Ministry) announced a call for projects for a strategy of HE development. The winner was a consortium composed by the firm Ernst \& Young Consulting and a liberal economic think tank called the Institute for Research on Market Economy (IBnGR) from Gdańsk. ${ }^{6}$ The diagnosis made by the consortium refers to the recommendations of the European Commission to set up a 'new model of HE, based on

\footnotetext{
${ }^{6}$ Founded in 1989 by liberal economists close to the first democratic governments, this institute has provided scientific justification and expertise to the process of privatisations of state property. It is the home institution of the present Polish Commissioner for financial programming and budget, Janusz Lewandowski.
} 
leadership, management and entrepreneurship and not only on academic freedom and internal democracy' (Ernst \& Young, 2009: 17). The reference to reforms conducted in Western European countries calls for 'the reduction of the role of the state and an increased university autonomy; the diversification of HEI; the concentration of research expenditure in the strongest universities; the professionalisation of the management system' (ibid). Thus the report clearly takes a stance in favour of management methods inspired by the private sector. The 2011 Act on HE is meant to create "synergies" with the package of legislative acts reforming the research system, which have, since the previous year, reorganised the existing system on a much more competitive base. Two new research agencies - the National Science Centre and the National Centre for Research and Development - finance research through a call for projects procedure. The $2011 \mathrm{HE}$ Act reinforces the tendency to employ academic teachers on temporary contracts. Individual researchers and academic teachers are evaluated at least every two years (Art. 132). Those who are deemed insufficiently productive may be fired (Art. 124, Art. 132). The assistants or assistant professors who did not manage to successfully defend their $\mathrm{PhD}$ or "habilitation" (the right to supervise $\mathrm{PhD}$ research) within 8 years of their appointment must resign their previous functions (Art 120). The generalisation of academic research evaluation appears as a political attempt to reposition the domestic HE system in the context of international competition and increasing influence of global university rankings (Erkkilä, 2013). In 2012, the ministry earmarked extra funds to reward the country's 25 best faculties (selected upon parametric evaluation and quantitative indicators of 'scientific effectiveness'). These National Leading Research Centres (KNOW), an excellence initiative of sorts, should receive up to 12,5 million euros each within five years.

The 2011 HE Act refers to the Bologna Process, suggesting a stronger internationalisation of the system and a better quality of teaching expected from the focus on learning outcomes with explicit references to the European Qualifications Framework. However this reform does not 
introduce the generalisation of fees. This may be considered as a tactical choice, as the government considered the issue as electorally dangerous (Interview, HE expert, 28 April 2011). This shows that domestic priorities allow for bypassing the recommendations of the OECD and of the European Commission, which have repeatedly called for the diversification of HE revenues. Finally the 2011 HE Act also introduces a number of mechanisms enabling closer ties with the economic environment. It foresees to include representatives of employers in certain consultative HE bodies and it compels HEI to install a follow up of the professional careers of their alumni. However, it does not propose any radical reform of university governance. The 2010 and 2011 reforms have tried to reorient the existing system around the terms of 'competitiveness', 'efficiency' and other economic logics such as the opening up of universities to the employers. While this discourse seems to be broadly accepted, it has also shown several limitations.

\section{The social perceptions of competition imperative}

Although it is difficult to evidence a causal relationship between the views expressed by the experts and those of the larger public, existing studies indicate that a large proportion of respondents, regardless of their social category, tend to consider education in an instrumental manner. Contrary to the socialist period, the opinion that the level of competence can be directly correlated with the position on the market seems to be widely shared (Białecki 1998). The context of democratic and economic transition explains the generally positive associations with the notions of competition and market rules, also applied to HE, even if a changing attitude towards liberal values may be observed among members of the younger generation (Bielska, 2006). Because of its opposition to the communist period, its economy of shortages and central planning, the liberalisation of public services seems to be more widely supported in Poland than in some Western European countries (Gaxie \& al. 2011). 
This can be observed on the political level, where the successive HE reforms did not spark major controversies. During parliamentary debates, politicians on the left did not oppose the principle of competition between HEI, even if they introduced more social accents in their discourse. Some of them invoked demographic rather than economic factors to justify the imperative of competition between HEI (Interview with an MP, 27 April, 2011). To understand the conditions of this political consensus building, we have to take into account the uneasy positioning of the left parties after 1989. As a successor to the former communist party, the Democratic Left Alliance (SLD) has opted since the 1990s to support liberal reforms and the EU accession. Thus, it could not disapprove of a reform presented as a means to 'catch up with Europe'.

However, although it is rarely contested as a basic means to differentiate the country's HEI, the principle of competition elicits more hesitant appreciations once it is evoked in its international dimension. While most HE experts acknowledge the necessity to face global competition pressures, their views concerning the chances of Polish universities to strengthen their position in this game diverge. All in all, in CEEC, the narratives on the necessity to catch up with the West have played an important role. In these countries the Bologna Process has been largely entangled with the EU accession negotiations. This factor contributes to the perception of the EHEA provisions as a non-negotiable package, which should be implemented as soon as possible and transposed in the national legislation.

\section{Conclusion}

The successive reforms of the Polish HE system redefined the role of the state without limiting it radically. While the opening up of the sector to market mechanisms has led to the emergence of a large private sector, the state nevertheless has retained much of its prerogatives in designing standard curricula of teaching, throughout the 1990s and until the 
2011 reform. While with the 2011 Act universities have gained more autonomy in defining their curricula, the ministry attempts to steer HEI through the keywords of quality and competitiveness.

The Polish case illustrates a more general tendency characterised by the government's use of the competitiveness imperative in order to diversify HEI. On another scale, the Russian government has moved toward a similar direction (Sigman, 2014, forthcoming). In the UK, central government control has been strengthened as a result of attempts to promote market mechanisms (Naidoo, 2008). According to Rajani Naidoo (2008), the promotion of market mechanisms serves the political project of changing the habitus of students and of the teaching staff and thus sets up a 'competitive state'.

The creation of favourable conditions for the development of the Polish private HE sector was the result of a deliberate policy crafted by the new democratic and liberal elites after 1989 . This policy had entailed some unintended consequences, such as the massive development of the private sector. There were few attempts to regulate this sector, as this existing offer allowed to broaden the access to HE to a large proportion of an age group, in conformity with international recommendations. While the most recent HE reform introduces some limits to the expansion of the non-public sector, it seems that the principal mechanism to limit the number of students opting for private education is a demographic one. As a result, some private HEI face difficulties in attracting a sufficient number of clients. This may lead them to reconsider issues of quality and of the relationship between the educational offer and the job market.

The reforms in CEEC over the last twenty years were inspired by heterogeneous rationales, which cannot be reduced to adjusting to the EHEA and European Research Area (ERA). Still, the Polish case shows that the European frameworks and recommendations are used strategically by policy makers. There is a noticeable convergence between the local reformist 
discourse and a certain type of official Bologna discourse, which insists on making 'Europe competitive by producing a viable, modern and adaptable workforce which is capable of meeting the dynamic challenges of a knowledge society' (Rozsnyai 2003: 280).

Successive legislative acts have tried to institutionalise the principles of competition, quality assurance and several curricula reforms. However, the implementation of these provisions has yet to be specified. The rapprochement with the job market has so far remained largely a statement of intent. The monitoring of the alumni's careers is not yet a common practice. European strategies such as Education and Training 2020 provide both a challenge and an opportunity for domestic policy makers to reform the existing system. The Bologna Process has triggered a rethinking of teaching methods and of the student-teacher relationship. However, in spite of the changes affecting the academic profession, some structural patterns such as the dominantly local recruitment of academic teachers continue to be observed. The competitive financing of research projects appears to benefit research centres and departments that were already dominant at the national level. Overall, European recommendations have fuelled governmental policies and were translated according to their reform ambitions.

\section{$\underline{\text { References }}$}

Altbach, Ph. G. \& Levy, D. C. (Eds.) (2005). Private Higher Education. A Global Revolution. Rotterdam/Taipei: Sense Publishers.

Altbach Ph. G. (2005). The Private Higher Education Revolution: An Introduction, in: Ph. G. Altbach \& D. C. Levy (Eds.), Private Higher Education. A Global Revolution. Rotterdam/Taipei: Sense Publishers.

Amaral A., Neave G., Musselin C. et Maassen P. (Eds.) (2009). European Integration and the Governance of Higher Education and Research. Dordrecht: Springer.

Bache, I. (2006). The Europeanization of Higher Education: Markets, Politics or Learning?. Journal of Common Market Studies, 44 (2), 231-248. 
Baisnée, O. \& Pasquier R. (Eds.) (2007). L’Europe telle qu'elle se fait. Européanisation et sociétés politiques nationales, Paris: CNRS Editions.

Batory, Agnes and Nicole Lindstrom (2011). The Power of the Purse: Supranational Entrepreneurship, Financial Incentives and European Higher Education Policy. Governance 24(2): 311-329.

Białecki, I. (1998). Introduction, in: Białecki I., Sikorska J. (Eds.), Wykształcenie i rynek (Education and market). Warsaw: Tepis.

Bielska E. (2006). Studenci à liberalny system wartosci w Polsce i w Danii. Gdansk, GWP.

Bruno I. (2008), À vos marques, prêts... cherchez. La stratégie européenne de Lisbonne, ves un marché de recherché, Bellecombe: Editions du Croquant.

Curaj, A., Scott, P., Vlasceanu, L., Wilson L. (Eds.) (2012). European Higher Education at the Crossroads. Between the Bologna Process and National Reforms (Part 1 and 2), Dordrecht: Springer.

Dale, R. and Robertson S. (Eds.) (2009). Globalisation and Europeanisation in Education. Oxford: Symposium Books.

Gaxie D, Hubé N., Rowell J., (Eds.) (2011). Perceptions of Europe. A Comparative Sociology of European Attitudes. Essex: ECPR Press.

Ernst \& Young Business Advisory \& Instytut Badań nad Gospodarką Rynkową (2009). Diagnoza stanu szkolnictwa wyższego w Polsce. Report published in November 2009, http://www.nauka.gov.pl/fileadmin/user_upload/Finansowanie/fundusze_europejskie/PO_KL/ Projekty_systemowe/20100727_SSW2020_strategia.pdf

Gornitzka, A. (2007). What is the Use of Bologna in the National Reform? The Case of Norwegian Quality Reform in Higher Education, in: V. Tomusk (Ed.), Creating the European Area of Higher Education. Voices from the Periphery. Dordrecht: Springer. 
Graziano, P. R., Jacquot S. and Palier B. (2011). Domestic Reconciliation Policies and the Usages of Europe. European Journal of Social Security 13(1), 3-25.

Guiraudon V., Favell A. (Eds.) (2011). Sociology of the European Union. Palgrave Macmillan.

GUS - Central Statistical Office (2011). Higher Education Institutions and their Finances in 2010. Warsaw: Statistical Information and Elaborations.

Higher Education Act (2011) (Ustawa z dnia 18 marca 2011 r. o zmianie ustawy - Prawo o szkolnictwie wyższym, ustawy o stopniach naukowych i tytule naukowym oraz o stopniach i tytule w zakresie sztuki oraz o zmianie niektórych innych ustaw).

Jabłecka, J. (1994). Reflections on the Polish Higher Education, in: Białecki, I. \& DąbrowaSzefler, M. (Eds.), Changes in Higher Education in Central European Countries, Centre for Science Policy and Higher Education. Warsaw: East-West Science Center/University of Kassel).

Jabłecka, J. (2007). Legitimation of Nonpublic Higher Education in Poland, in: Slantcheva, S. \& Levy, D. C. (Eds.), Private Higher Education in Post-Communist Europe. In search of legitimacy. Houndmills: Basingstoke, Palgrave Macmillan.

Jabłecka, J. (2009). Revolution and evolution in the organization of public research funding in Poland between 1991 and 2007, in: J. Jabłecka, Public research funding. Research councils, funding instruments, evolution of the system in Poland. Warsaw: Centre for Science Policy and Higher Education, University of Warsaw.

Jackowski, S. (2004). Uczelnie na zakręcie (Universities at the crossroads), Forum Akademickie, $n^{\circ} 3$.

Jajszczyk, A. (2008a). Polskie uniwersytety potrzebują reanimacji (Polish universities need reanimation), Rzeczpospolita, 26 February 2008. 
Jajszczyk, A. (2008b). Siedem grzechów głównych szkolnictwa wyższego w Polsce (The seven deadly sins of Polish HE), Infos, Biuro Analiz Sejmowych, 9(33), 8 May 2008.

Kehm B. (2012), Editorial, European Journal of Education, 47, $n^{\circ} 3,2012,343-347$.

Keeling, R. (2006). The Bologna Process and the Lisbon Research Agenda: The European Commission's Expanding Role in Higher Education Discourse, European Journal of Education, 41 (2), 203-222.

KRASP, FRP, KRZaSP. 2009. Polskie Szkolnictwo Wyższe. Stan, uwarunkowania, perspektywy, Warsaw http://www.krasp.org.pl/pl/strategia/strategia

Krücken G., \& Serrano-Velarde, K. (2012), Editorial, European Journal of Education, 47 (2), 173-177.

Kwiek, M. (2007). The European Integration of Higher Education and the Role of Private Higher Education, in: S. Slantcheva, D. C. Levy (Eds.), Private Higher Education in PostCommunist Europe. In search of legitimacy. Houndmills, Basingstoke: Palgrave Macmillan). Lane, J. E., Kinser, K. (2011). Reconsidering Privatisation in Cross-Border Engagements: The Sometimes Public Nature of Private Activity, Higher Education Policy, 24, 255-273.

Levy, D. C. (2012). How Important Is Private Higher Education in Europe? A Regional Analysis in Global Context, European Journal of Education, 47, n² 2, 178-197.

Marginson, S. (2007). The public/private divide in higher education: A global revision, Higher Education, 53, 307-333.

Muller P. and Ravinet P. (2009). Construire l'Europe en résistant à l'UE ? Le cas du processus de Bologne, Revue internationale de politique comparée, 16, n 1, 653-665.

Musselin, C (2009). The Side Effects of the Bologna Process on National Institutional Settings : The Case of France, in : Amaral A., \& al. (Eds.) (2009). European Integration and the Governance of Higher Education and Research. Dordrecht: Springer.

Naidoo Rajani (2003). Repositioning Higher Education as a Global Commodity: 
Opportunities and Challenges for Future Sociology of Education Work, British Journal of Sociology of Education (24 (2), p. 249-259).

Naidoo Rajani (2008). L’État et le marché dans la réforme de l'enseignement supérieur au Royaume Uni (1980-2007), Critique internationale, 2, n 39, p. 47-65.

Neave, G. (2007). The Long Quest for Legitimacy. An Extended Gaze from Europe's Western Parts, in: S. Snejana \& D. C. Levy (Eds.), Private Higher Education in PostCommunist Europe. In search of legitimacy. Houndmills, Basingstoke: Palgrave Macmillan. Pabian, Petr (2009). Europeanisation of Higher Education Governance in the Post-Communist Context: The Case of the Czech Republic, in European Integration and the Governance of Higher Education and Research in : Amaral A., \& al. (Eds.) (2009). European Integration and the Governance of Higher Education and Research. Dordrecht: Springer.

Ratajczak, M., (2004). Unia Personalna (Personal Union), Forum Akademickie n².

Radaelli, Claudio M. 2001. 'The Domestic Impact of European Union Public Policy: Notes on Concepts, Methods, and the Challenge of Empirical Research'. Politique europeenne 5: 107142.

Schultheis, F., Roca i Escoda M., Cousin P.-F. (Eds.), (2008). Le cauchemar de Humboldt. Les réformes de l'enseignement supérieur européen. Paris: Raisons d'agir.

Sigman Carole (2014). Les transformations de l'enseignement supérieur en Russie: évolution du secteur public et stratégies d'établissements, Revue d'Études Comparatives EstOuest, $\mathrm{n}^{\circ}$, forthcoming in March.

Slantcheva, S., Levy, D. C. (Eds.) (2007). Private Higher Education in Post-Communist Europe. In search of legitimacy. Houndmills, Basingstoke: Palgrave Macmillan.

Szabłowski, J. (2004). Projekt wymaga modyfikacji (The project needs modifications), Forum Akademickie, $\mathrm{n}^{\circ} 2$. 
Thieme, J. K. (2009). Szkolnictwo wyższe. Wyzwania XXI wieku. Polska. Europa. USA (Higher Education. Challenges of the 21st Century. Poland. Europe. USA). Warsaw: Engram. Vukasovic M., Maassen P., Nerland M., Stensaker B., Pinheiro R., Vabø A. (Eds.), (2012.), Effects of Higher Education Reforms: Change Dynamics. Rotterdam: Sense.

Walkenhorst, H. (2008). Explaining change in EU education policy, Journal of European Public Policy. 15(4), 567-587.

Woll, C., Jacquot, S. (2010). Using Europe: Strategic Action in Multi-Level Politics. Comparative European Politics, 8 (1), 110-142.

World Bank (2004). Tertiary Education in Poland. Warsaw. 